\title{
PENGALAMAN PASIEN KANKER SERVIKS DALAM MENGATASI KECEMASAN
}

\author{
Dameria M. Sinaga ${ }^{1}$, Heru Santosa ${ }^{2}$, Namora Lubis ${ }^{3}$ \\ Departement of Health Promotion, Faculty of Publich Health, University of Sumatera Utara ${ }^{123}$ \\ Email :'dam.s1076@yahoo.com, ${ }^{2}$ heru_php2@yahoo.com, ${ }^{3}$ namoralubis041072@gmail.com
}

\begin{abstract}
Cervical cancer is a disease that causes problems in the lives of women who experience it related to the decline in the role of wife and mother and the quality of life. Generally women with cervical cancer come at an advanced stage so they experience depression which is characterized by an attitude of anger, self-closure and lack of acceptance of his condition. This study aims to explore of cervical cancer patients in resolve of anxiety. This research is qualitative with a phenomenological approach. Data collection is done by indepth interview and fieldnote. The subjects of study were five patients of cervical cancer where selected using a purposive sampling technique. Interviews were conducted at the hospital and at the homes of participants who were then analyzed using the Collaizi method. The results of the research analysis discovered four themes namely, experiencing psychological changes, experiencing changes in interacting, getting social support and carrying out spiritual activities. From the results of the study suggested that cervical cancer patients need the support of family, work colleague and fellow cervical cancer friends, doing more spiritual activities by praying and being sincere in receiving and undergoing treatment.
\end{abstract}

Keywords: resolve; anxiety; cervical cancer

\begin{abstract}
ABSTRAK
Penyakit kanker serviks merupakan penyakit yang menimbulkan permasalahan pada kehidupan wanita yang mengalaminya terkait akan penurunan peran sebagai istri dan ibu serta kualitas hidupnya. Umumnya wanita dengan kanker serviks datang pada stadium lanjut sehingga mereka mengalami depresi yang ditandai dengan sikap marah, menutup diri dan kurang menerima keadaan dirinya. Penelitian ini bertujuan untuk mengeksplorasi pengalaman pasien kanker serviks dalam mengatasi kecemasan. Penelitian ini bersifat kualitatif dengan pendekatan fenomenologi. Pengumpulan data dilakukan dengan cara indepth interview dan fieldnote. Partisipan berjumlah lima orang pasien kanker serviks yang dipilih menggunakan teknik purposive sampling. Wawancara dilakukan di rumah sakit dan di rumah partisipan yang kemudian dianalisis dengan menggunakan metode Colaizzi. Hasil analisis penelitian ditemukan empat tema yaitu, mengalami perubahan psikologis, mengalami perubahan dalam berinteraksi, memperoleh dukungan keluarga dan melakukan aktifitas spiritual. Dari hasil penelitian disarankan pasien kanker serviks membutuhkan dukungan keluarga, teman sekerja dan teman sesama kanker serviks, lebih banyak melakukan aktifitas spiritual dengan berdoa dan ikhlas dalam menerima dan menjalani pengobatannya.
\end{abstract}

Kata kunci: pengalaman;kecemasan;kanker serviks.

\section{PENDAHULUAN}

\section{Latar Belakang}

Penyakit kanker adalah bagian dari penyakit tidak menular yang merupakan penyebab kematian yang utama di dunia saat ini setelah penyakit jantung dan pembuluh darah. Data World Health Organization (WHO) tahun 2012 menyatakan kematian yang terjadi didunia setiap tahunnya sebanyak 8,2 juta jiwa disebabkan oleh kanker, dan hanya 1/3 kejadian kematian penyakit tersebut terjadi di negara maju. ${ }^{16}$ Tahun 2015 WHO melaporkan bahwa kematian yang disebabkan oleh penyakit kanker masih tinggi diseluruh dunia sebanyak 13\% yaitu 7.540.000 kematian dari 58 juta kematian yang ada di dunia. ${ }^{19}$

Pada wanita penyebab kematian yang utama adalah kanker serviks. Kanker serviks menempati urutan kelima penyebab kematian di dunia dan menempati urutan pertama pada wanita. Kanker serviks banyak ditemukan pada wanita di negara berkembang lainnya di Asia termasuk Indonesia. Data Yayasan Kanker Indonesia menyebutkan ada sebanyak $70 \%$ 
kanker serviks terdapat pada wanita dinegara berkembang dan yang terbanyak terdapat di Asia Tenggara. ${ }^{20}$ WHO (2014) menyatakan bahwa di Indonesia ada 20.928 wanita yang menderita kanker serviks dan yang meninggal dunia sebanyak 9.498 penderita. Kanker serviks merupakan penyakit keganasan yang menimbulkan masalah dalam kesehatan wanita. ${ }^{18}$

Negara Indonesia merupakan salah satu kelompok negara sedang berkembang dimana angka kejadian kanker serviks tinggi. ${ }^{12}$ Data dari Yayasan Kanker Indonesia tahun 2015, penderita kanker serviks sebanyak 12.000 , dan yang meninggal sebanyak 8000 orang. Dimana 70\% dari 8000 penderita kanker serviks yang meninggal dunia, datang dan mengetahui diagnosa mereka pertama sekali sudah pada stadium lanjut. ${ }^{20}$

Kecemasan mulai dirasakan penderita mulai dari memeriksakan diri ke dokter, dan mendapatkan diagnosa kanker serviks. Pasien belum siap menerima dirinya mengidap kanker serviks dan harus menjalani radioterapi dan kemoterapi membuat meningkatnya kecemasan pasien. ${ }^{6}$ Efek pengobatan yang dilakukan pada pasien yang dapat menimbulkan penurunan fisik juga semakin menguatkan kecemasan pasien semakin bertambah. Kecemasan yang dialami pasien dapat mempengaruhi kondisi pasien pada saat menjalani proses pengobatan.?

Kanker serviks sangat berhubungan dengan rasa nyeri dan cemas serta banyaknya rasa sakit, ini menyatakan bahwa gejala dan pengobatan kanker serviks menjadikan faktor kecemasan yang utama yang mengakibatkan turunnya kondisi fisik, kualitas hidup dan hubungan dengan keluarga terdekat. Hal ini sangat penting diketahui agar dapat memahami akan strategi atau cara mengatasi kecemasan yang ada. Demikian pula pada masa pengobatan pasien banyak situasi yang menimbulkan kecemasan pasien seperti biaya pengobatan, efek dari pengobatan dan juga kematian yang menjadikan kecemasan pada pasien.

Kecemasan yang sering timbul pada pasien umumnya perubahan tingkah laku, panik, tidak dapat berkonsentrasi, gelisah, ketakutan, jantung berdegup lebih kencang dan tangan yang berkeringat serta kualitas tidur yang menurun. ${ }^{2}$ Kecemasan itu dirasakan pasien, apabila pasien mengingat kematian ataupun keadaan yang tidak baik yang akan terjadi pada pasien dikemudian hari.
Lubis (2009) menyatakan bahwa kecemasan adalah tanggapan dari sebuah ancaman nyata ataupun khayal. ${ }^{6}$ Sedangkan Kaplan (2010) memahami bahwa kecemasan adalah respon terhadap situasi tertentu yang mengancam dan merupakan hal yang tidak normal terjadi menyertai perkembangan, perubahan, pengalaman baru atau yang belum pernah dilakukan serta dalam menemukan identitas diri dan arti hidup. ${ }^{4}$ Kecemasan yang dimiliki pasien dapat mempengaruhi kualitas hidup bahkan hubungan dengan anggota keluarga lainnya.

\section{Tujuan Penelitian}

Adapun tujuan penelitian ini dilakukan untuk mengeksplorasi pengalaman pasien dalam mengatasi kecemasan pada saat sudah terdiagnosa kanker serviks dan juga di tahap pengobatannya. Hasil wawancara mendalam yang dilakukan pada pasien kanker serviks didalam mengatasi kecemasan diantaranya dengan menjalani proses pengobatan secara teratur, selalu optimis atau berpikiran positif, mengikuti terapi kelompok, mengikuti kelompok konseling kanker, memperoleh dukungan keluarga, ikhlas dan lebih banyak berdoa pada Tuhan.

\section{METODE}

Penelitian ini bersifat kualitatif dengan pendekatan fenomenologi. ${ }^{1}$ Teknik pengambilan informan dengan cara purposive sampling dan kriteria inklusi partisipan adalah pasien yang sudah didiagnosa kanker serviks, sudah dikemoterapi, mampu menceritakan kecemasan yang dialaminya, bersedia diwawancara dan masih usia produktif. Penelitian ini dilakukan di RSUD dr. Pirngadi Medan kepada lima informan dimana informan ditemui di ruang rawat inap dan ruang kemoterapi. Pengumpulan data dilakukan dengan wawancara mendalam dengan alat tape recorder berdasarkan panduan wawancara. ${ }^{9}$ Hasil wawancara disusun ke dalam transkrip yang selanjutnya dianalisis menggunakan pendekatan Collaizi. $^{1}$

\section{HASIL}

Partisipan didalam penelitian ini berjumlah lima orang pasien kanker serviks dan memenuhi kriteria yang telah ditentukan (inclution criteria). Karakteristik demografi dapat dilihat di tabel 1. 
Tabel 1. Karakteristik Demografi Partisipan

\begin{tabular}{llll}
\hline $\begin{array}{l}\text { Data Demografi Partisipan } \\
\text { F }\end{array}$ & & \\
\hline Umur & $\leq 40 \quad$ tahun & 1 & 20 \\
& $41-55$ tahun & 3 & 60 \\
& $\geq 56 \quad$ tahun & 1 & 20 \\
Agama & Kristen & 3 & 60 \\
& Islam & 2 & 40 \\
Pekerjaan & IRT & 4 & 80 \\
& PNS & 1 & 20 \\
Diagnosa & II & 3 & 60 \\
stadium & III & 2 & 40 \\
\hline
\end{tabular}

Hasil penelitian ini diperoleh empat tema yaitu, mengalami perubahan psikologis, mengalami perubahan dalam berinteraksi, memperoleh dukungan sosial dan melakukan aktifitas spiritual.

\section{Tema 1. Mengalami perubahan psikologis}

\section{Menangis}

Hampir semua partisipan dalam mengungkapkan kecemasan penyakitnya dengan menangis, sesuai dengan ungkapan :

"saya sangat terkejut dan langsung menangis"(P2)

"saya sering menangis di kamar apabila mengingat penyakitku”(P3)

"setelah didiagnosa dokter, saya hanya bisa menangis dan menangis"(P5)

\section{Kecemasan}

Partisipan merasakan kecemasan yang tinggi dengan kondisinya sekarang, berikut ungkapannya :

"saya sangat cemas, apalagi penyakit ini sangat mematikan" $(\mathrm{P} 1)$

"perasaan saya cemas sekali terutama anakanak masih sekolah"( $\mathrm{P} 3)$

"bagaimana tidak cemas,bu...dada saya sesak mengingat penyakit saya ini" (P4)

3. Ketakutan

Partisipan mengungkapkan ketakutannya akan kematian yang akan menghampirinya, berikut ungkapannya :

"saya terkejut dan takut karena dalam pikiran saya bahwa penyakit kanker itu tidak bisa sembuh dan pasti mati"(P1)

"setiap mengingat penyakit ini, maka kematian saya sudah dekat”(P5)
Tema 2. Mengalami perubahan dalam berinteraksi

1. Interaksi didalam keluarga

Penyakit yang diderita partisipan berpengaruh pada keharmonisan komunikasi didalam keluarga, berikut ungkapan partisipan :

"saya sering termenung di rumah dan malas untuk bicara pada suami dan anakanak"(P1)

"dirumah saya suka marah-marah pada suami dan anak-anak"(P4)

2. Interaksi didalam sosial masyarakat

Dampak interaksi partisipan akibat penyakit yang diderita juga berpengaruh pada interaksi sosial masyarakat, seperti ungkapan berikut ini :

"saya merasa tidak berguna dan malas untuk keluar-keluar gabung dengan tetangga"( $\mathrm{P} 2)$

"undangan-undangan sudah sering tak datang aku, lebih baik kuhindari"(P5)

\section{Tema 3. Memperoleh dukungan sosial}

\section{Dari keluarga}

Kecemasan dan ketakutan yang melanda partisipan akan berkurang apabila didukung dan diberi semangat dari suami dan anak-anak, berikut ungkapannya :

"kecemasan saya berkurang pada saat keluarga selalu memberikan semangat dan menemani saat konsul dan kemoterapi"'(P2)

“....bersyukur pada Tuhan bahwa suami baik selalu mendengarkan keluhan dan kekhawatiran saya tentang penyakit ini'"(P3)

\section{Dari teman sekerja}

Dukungan yang didapatkan partisipan tidak hanya dari keluarga tetapi juga diperoleh dari teman sekerja, seperti ungkapannya :

"saya sangat bersyukur memiliki temanteman dikantor yang peduli..kadang mereka nelpon dan wa untuk memberikan semangat"'(P3)

"karena saya kader, teman-teman sering ke rumah dan ibu kepling juga sering kerumah melihat saya"(P5)

3. Dari sesama penderita

Mengatasi kecemasan dapat dialami partisipan dengan saling membagi pengalaman ataupun sharing sesama partisipan terutama sama-sama menjalani kemoterapi yang dilakukan, seperti ungkapan dibawah ini :

"kau harus kuat dan tegar, lihat anakanakmu..kalau kau nangis terus maka kondisimu drops dan suamimu lekas kawin"(P2) 
"kau harus optimis, lihat aku..stadiumku lebih parah dari kau tapi aku tetap hidup sampai sekarang"(P3)

\section{Tema 4. Melakukan aktifitas spiritual}

\section{Sering berdoa}

Setelah partisipan mengetahui bahwa menderita kanker serviks, mereka lebih sering berdoa walaupun tidak harus pergi ke mesjid/gereja, seperti ungkapan berikut ini :

“...saya langsung berdoa pada Allah sambil menangis, dengan berdoa padaNya saya sedikit lega dan cemas sedikit berkurang"'(P1)

"kalau saya bangun tengah malam, saya langsung berdoa. Jadi lebih sering berdoa kalau bangun tengah malam"(P3)

"saya mencoba berpikiran positif dan selalu berdoa agar diberikan umur yanng panjang"'(P4)

2. Ikhlas dan berharap

Partisipan mengakui dalam mengatasi kecemasan harus lebih ikhlas dan terus berharap kan kesembuhan melalui pengobatan yang dilakukan, seperti ungkapan dibawah ini :

"kadang cemas ini muncul, saya berdoa dan ikhlas menjalani yang terjadi sambil berharap pada Allah pasti memberikan kesembuhan"(P1)

“...awalnya saya cemas, tetapi sekarang setelah kemoterapi saya lebih optimis dan berharap akan kesembuhan penyakitku" (P3)

"harapan saya bisa kembali kumpul dengan keluarga dan menjalani pekerjaanku seperti semula"(P5)

\section{PEMBAHASAN}

Perubahan psikologis yang dirasakan partisipan hampir seluruhnya memiliki bentuk kecemasan yang sama seperti sedih dan menangis, berdiam diri, cemas dan ketakutan serta sulit tidur. Tidak berbeda dengan temuan penelitian Nugroho 2008 yang menyatakan adanya bentuk-bentuk kecemasan yang timbul pada subjek penelitiannya biasanya perubahan tingkah laku, kedinginan dan telapak tangan lembab, tidak mampu berkonsentrasi atau tidak memahami penjelasan, tidak mampu menyimpan informasi yang diberikan dan merasa gelisah. ${ }^{10}$

Tidak berbeda dengan temuan pada penelitian Rahmah (2016) yang dilakukan dengan cara wawancara mendalam dengan menggunakan studi kasus pada empat partisipan yang menunjukkan bahwa didapati adanya kecemasan dengan aspek kognitif seperti tubuh bergetar pada awal diagnosa, susah tidur di malam hari dan sering menangis ketika malam hari, merasa malu bahkan ingin menyendiri setelah didiagnosa kanker serviks. ${ }^{13}$ Ada partisipan yang mengatakan mempunyai ketakutan jika dirinya nanti tidak dapat sembuh dan ada juga dilanda ketakutan karena tidak ada biaya untuk pengobatannya.

Pada penelitian ini dapat diketahui bahwa pengalaman pasien dalam hal mengurangi kecemasannya adalah dengan berdoa dan memperoleh dukungan dari keluarga termasuk suami dan anak-anak yang selalu menemani di kala pasien melakukan pengobatan yang dianjurkan oleh dokter dan juga menemani pada saat pasien menjalani kemoterapi.

Keluarga yang merupakan unit terkecil dari masyarakat memiliki peranan yang sangat penting dalam mengurangi kecemasan pasien. ${ }^{3}$ Informan menyatakan bahwa dalam mengurangi kecemasan yang timbul pada diri mereka pada saat mereka mengingat akan ketidakpastian kesembuhan penyakit mereka maka dukungan keluarga baik suami dan anak-anak yang selalu disampingnya membuat pasien nyaman dan tenang. Hal ini sejalan dengan penelitian dari Rahmah (2016) yang menyatakan bahwa pada umumnya informan dalam mengatasi kecemasan dengan mendapatkan dukungan dari keluarga selama informan sakit baik. ${ }^{13}$ Informan mengatakan bahwa perhatian keluarganya menjadi lebih banyak semenjak keluarga mengetahui informan didiagnosa menderita kanker leher rahim dimana keluarga lebih memperhatikan makanan yang dianjurkan dan yang tidak boleh pada pasien kanker serviks juga lebih sering memberikan informasi kesehatan tentang kanker serviks.

Hasil penelitian ini sejalan dengan penelitian Susilawati (2015) yang menyatakan adanya hubungan dari dukungan keluarga dengan tingkat kecemasan pasien kanker serviks. ${ }^{15}$ Adanya dukungan keluarga yang intens terhadap pasien kanker serviks membuat pasien lebih merasa diperhatikan dan dibutuhkan sehingga lebih semangat menjalani hidup dan semakin mengurangi kecemasan. ${ }^{13}$ Bentuk dari dukungan keluarga dapat berupa dukungan emosional, dukungan penghargaan, dukungan materi dan dukungan informasi. ${ }^{3}$ Dimana dukungan keluarga ini sangat mempengaruhi psikis dari pasien kanker leher rahim. 
Demikian pula halnya dengan penelitian Kusumaningrum (2016) menyatakan bahwa pasien kanker serviks mendapat dukungan dari keluarga dalam menghadapi penyakit dan pengobatannya. ${ }^{5}$ Keluarga yang memiliki lima tugas kesehatan keluarga dapat membantu anggota keluarga yang sakit menderita kanker serviks dapat mencapai kondisi yang lebih baik secara fisik maupun psikologis. ${ }^{3}$ Keluarga yang baik menjalankan tugas kesehatannya akan mampu mengurangi kecemasan dari pasien kanker serviks. ${ }^{21}$ Keluarga yang menjalankan tugas perawatan pasien walaupun terbatas dapat berupa menemani kontrol atau berobat, mengingatkan jadwal mendapat tindakan kemoterapi dan memperhatikan diet yang dapat dikonsumsi penderita kanker serviks.

\section{KESIMPULAN}

Seluruh informan mengalami kecemasan dimana pada saat pertama sekali didiagnosa oleh dokter mengidap penyakit kanker serviks. Dari lima informan kecemasan muncul bukan hanya di awal didiagnosa dokter tetapi juga saat proses pengobatan radioterapi dan kemoterapi.

Kecemasan yang timbul berbeda-beda pada pasien satu dengan yang lainnya, seperti jantung berdegup, susah tidur, menangis, tangan berkeringat, kurang fokus, kerongkongan kering, marah dan kurang percaya diri. Kelima informan menyatakan bahwa dalam mengatasi kecemasan pasien maka dukungan keluarga sangat mempengaruhi.

Selain dari dukungan keluarga yang pada umumnya dapat mengatasi kecemasan pasien yaitu berbagi pengalaman pada teman yang sama-sama menderita penyakit kanker serviks.

\section{DAFTAR PUSTAKA}

1. Creswell J. W. Research Design, Qualitative, Quantitative and Mixed Methods Approaches.4th ed. Yogyakarta: Pustaka Pelajar; 2017. p. 245-285.

2. Fauziah R. Kecemasan pada Penderita Kanker, Universitas Muhammadiyah Jember, 2016.

3. Friedman M. Maryln. Keperawatan Keluarga : teori dan praktek (5th,ed). Jakarta: EGC; 2010.

4. Kaplan, H.I, Sadock,B.J. Retardasi Mental dalam Sinopsis Psikiatri. Tangerang: Binarupa Aksara; 2010.
5. Kusumaningrum. The Role Of Family And Quality Of Life In Patients With Cervical Cancer. Jurnal Ners. Surabaya: UNAIR; 2016. 11(1), p. 112-117

6. Lubis Namora. Hubungan Pasien Kanker Serviks Dengan Kecemasan. Sumatera Utara: USU Press; 2009.

7. Lubis Namora. Dukungan Sosial Pada Pasien Kanker, Perlukah ?. Sumatera Utara: USU Press; 2009. p. 49 - 58.

8. Lubis Namora. Dasar-Dasar Konseling Dalam Teori Dan Praktek. Sumatera Utara: USU Press; 2016. p. 36-55

9. Moleong L. J. Metodologi Penelitian Kualitatif. Bandung: Remaja Rosdakarya; 2002. p. 111-245

10.Nugroho. Keperawatan Gerontik. 3rd ed. Jakarta: Buku Kedokteran EGC; 2008.

11.Potter, P.A, Perry. A.G. Buku Ajar Fundamental Keperawatan : Konsep, Proses, dan Praktik. Edisi 4. Jakarta: EGC; 2005.

12.Kementrian Kesehatan RI. Profil Kesehatan RI: Data Penderita Kanker Serviks di Indonesia. Jakarta: Kementrian Kesehatan RI; 2016.

13.Rahmah. Kecemasan Pasien Dan Dukungan Keluarga Pada Penderita Kanker Servik. Jurnal Psikoborneo. Samarinda: Universitas Mulawarman. 2016; 4(4). p. 819 - 828.

14.Rasjidi, Imam. Epidemiologi Kanker Serviks. Indonesian Journal Of Cancer. Jakarta. 2009; 3(3).

15. Susilawati D. Hubungan Antara Dukungan Keluarga Dengan Tingkat Kecemasan Penderita Kanker Serviks Paliatif di RSUD dr. Sardjito Yogyakarta. Jurnal Keperawatan. 2012; 4(2): 87-99 ISSN 20863071,http://ejournal.umm.ac.id/index.php/ keperawatan/article/view/23583195

16. World Health Organization. International Agency For Research On Cancer. 2012. Enstimated Cancer Insidence, Mortality And Prevalence Worldwide In 2012. US: WHO; 2012. Available from : http://www.who.int/cancer.prevention/diagnos is-screening/cervical-cancer/en/.

17. World Health Organization. Cervical cancerglobal cancer observatory. France: WHO; 2014.

18. World Health Organization. Cancer Country Profiles. US: WHO; 2014.

19. World Health Organization. Global Map Presenting the National Rangking of Cancer. US: WHO; 2015. Available from : https://www.who.int/cancer_prevent. 
Jurnal Ilmiah Pannmed (Pharmacyst, Analyst, Nurse, Nutrition, Midwivery, Environment, Dental Hygiene)

Vol. 15 No.1 Januari - April 2020

20. Yayasan Kanker Indonesia (YKI). Data Prevalensi dan Kematian Pasien Kanker Indonesia. Jakarta; 2017. Available from : http://www.yayasan kanker indonesia.com.

21. Yuliyanti T, Zakiyah E. Tugas Kesehatan Keluarga sebagai Upaya Memperbaiki Status Kesehatan dan Kemandirian Lanjut Usia, Jurnal Profesi. 2016; 14(1). 